\title{
The Effect of Hands-On Minds-On Learning on Reducing Kindergarteners' Foreign Language Learning Anxiety
}

\section{Mai Ahmed Eassa El Nekhely}

Ph.D. student, Curriculum and TEFL Instruction, Faculty of Education, Ismailia, Egypt

\section{Abstract}

Thile research has mainly focused on foreign
language learning anxiety, its causes and
effects on the learning process and the ways to alleviate it among learners, it has rarely focused on foreign language learning anxiety among kindergarteners. Thus, this study aims at qualitatively investigating the effect of hands-on minds-on learning on reducing kindergarteners' foreign language learning anxiety. The sample group consisted of 21 experts and teachers of English as a foreign language in kindergarten. Interviews were conducted to collect qualitative data. Results revealed that hands-on minds-on learning can reduce foreign language learning anxiety among kindergarteners, and that much more research attention should be given to foreign language learning anxiety and to the use of hands-on minds-on learning in classes of teaching English as a foreign language in kindergarten.

Keywords: Foreign Language Learning Anxiety, Kindergarteners, Hands-On Minds-On Learning

\section{Introduction}

Kindergarten should be the place for young children to learn where they can try out new skills without fear of mistakes. Learning a foreign language has a lot of advantages during this phase. Shin (2019) referred to the critical period of teaching English as a foreign language (EFL) to young learners, and they pointed out that before reaching that period, learners are more flexible to learn a foreign language especially that this is a period when the brain is developing and maturing. 
In learning foreign languages, anxiety could reach its highest level (Subasi, 2010; Sung-Yeon, 2009, as cited in Thies, 2014) because learners are required to communicate using a language which they have not mastered perfectly (Tsiplakides and Keramida, 2009). Thus, it is necessary to study foreign language learning anxiety (FLLA) because it is an affective filter that could hinder the learners' capability in learning a foreign language (Rahimi and Mansoori, 2016), and their academic progress in later years when they are young learners (Cowden, 2010).

Although FLLA has been widely studied; few researchers (e.g. Choi, Sheo and Kang, 2020; Koolaee, Vazifehdar, Bahari, and Akbari (2016); Levy, 2011; Nilsson, 2019) have focused on FLLA of young learners (Nilsson, 2019), and thus, more research is needed to investigate young children's FLLA as children can quickly form negative attitudes toward learning English as a foreign language (Choi et al., 2020).

Concerning the significance of the current study, it can stem from the following points:

- Trying to fill in the gap of the little research that investigated FLLA among kindergarteners.

- Trying to fill in the gap of studies that applied handson minds-on learning to higher graders than kindergarteners and in the field of learning English as a foreign language rather than science and math.

- Combining both hands-on learning and minds-on learning in contrast to many studies which adopted only hands-on learning.

- Providing a relaxing and motivating environment to KG2 children while developing their EFL. 
As regards the hypothesis of the study which is qualitative, the following hypothesis can be formulated as follows "hands-on minds-on learning has a positive effect on reducing foreign language learning anxiety among kindergarteners."

FLLA is referred to as "a distinct complex of selfperceptions, beliefs, feelings, and behaviors related to classroom language learning arising from the uniqueness of the (foreign) language learning process" (Horwitz, Horwitz and Cope, 1986 p. 128, as cited in Rahimi and Mansoori, 2016). It is recognized as a type of anxiety that occurs when learning a foreign language (Choi et al., 2020).

Hands-on minds-on learning is the most efficient way in the learning process and it requires students to be physically and mentally involved (Ajaja, 2013, as cited in Ghosh, 2017). It combines two important factors that help kindergarteners to learn: the hands and the mind (Lebuffe, 1994, as cited in Ates and Eryilmaz, 2011).

The following research questions are central in this study: What are the perceptions of kindergarten's experts and EFL teachers about the effect of hands-on minds-on learning on reducing FLLA of kindergarteners? What is hands-on minds-on learning? What factors does hands-on minds-on learning involve that can reduce FLLA of kindergarteners?

\subsection{Kindergarteners}

Kindergarteners learn best through physical activities since motor skills can develop their brain (Ed, Church and Poole, 2016). They can explore their environment through doing things, and creating products (Corzine, Davy, Spicer and Jones, 2018), and they can learn best with concrete 
experiences (Blaustein, 2005). It is also very important to create a safe and warm environment for kindergartners as this will positively affect their progress in learning at schools (DeAngelis, 2010).

\subsection{Foreign Language Learning Anxiety (FLLA)}

Besides the cognitive domain (knowledge) and psychomotor domain (skills), there is the affective domain which relates to the feelings, motivations, and attitudes of the learners (Hoque, 2017). The affective factor is so important in learning, and especially in learning languages (Zapata, 2017).

The three aforementioned domains are integrated and disregarding anyone of them can affect the others. For instance, anxiety, one of the components of the affective domains in education, can work as an emotional block in learning the target language (Zapata, 2017), and causing less willingness to participate in learning activities (Tsiplakides et al., 2009), and thus, affecting the cognitive domain (Rahimi and Mansoori, 2016).

Anxiety is common in everyone; it is a normal part of development. There are two types of anxiety which are the general anxiety and the specific anxiety. The general anxiety relates to people who are anxious in various situations, whereas specific anxiety relates to people who become anxious in specific situations, such as using a foreign language (Horwitz, Horwitz, \& Cope, 1986, as cited in Kralova, 2016).

FLLA is recognized as a type of anxiety that occurs when learning a foreign language (Choi et al., 2020), and it is considered to be one of the most prominent factors for preventing success in foreign language learning (Nilsson, 2019). 
As regards the sources of FLLA, there are two main variables that determine these sources: situational variables and learner variables. The situational variables relate to classroom tasks, teacher behavior, level and type of courses, whereas the learner variables involve the learners' capability, personality, the learning styles and views (Rahimi and Mansoori, 2016). Some studies (e.g. Sun et al., 2015, as cited in Choi et al., 2020) focused on children's gender, age, and temperament as possible individual sources of FLLA.

As for age, which is another factor for FLLA, there was little research investigating FLLA among young children, as they are less anxious about making mistakes than older learners (Choi et al., 2020). In fact, older students can feel anxious out of fear of making mistakes (Tsiplakides et al., 2009), negative evaluation by others and test anxiety (Rahimi and Mansoori, 2016), and communication apprehension (Nilsson, 2019).

Like any type of anxiety, FLLA can be shown in features, such as sweating, trembling, difficult concentration and forgetfulness, (Horwitz, Horwitz, \& Cope, 1986, as cited in Kralova, 2016). It can also be shown in being hesitant to engage in communication for having feelings of embarrassment to use the new language (Gregersen \& MacIntyre, 2014, as cited in Nilsson, 2019).

Providing a non-threatening learning environment is essential for reducing FLLA among learners. This could happen by engaging them in activities that the learners enjoy doing, and which motivate them (Zapata, 2017). One of the methods to reduce FLLA is learning by doing. This could be achieved by engaging in hands-on learning activities and doing projects (Tsiplakides et al., 2009). 
Another method to alleviate FLLA is the use of manipulatives since they change the abstract into concrete (Sidiqi, 2017). A third method is using art and craft works which was found to alleviate anxiety. Studies (e.g. Levy, 2011; Nelson, 2018) have all assured that art and craft works, such as painting, coloring, drawing and modeling with clay reduced the level of anxiety among participants.

A fourth method is using assessment techniques which differ from traditional tests, such as hands-on tasks and using manipulatives (Shaaban, 2001), besides observations and task-based assessments (Emery, 2018). This safe environment which is free from test anxiety especially for kindergarteners will positively affect their progress in learning at schools (DeAngelis, 2010).

\subsection{Hands-on Minds-on Learning}

Students learn more by not being told but by doing things themselves (Sumil, 2016). Looking back to the history of the origin of hands-on minds-on learning, it is believed that John Dewey was the first advocate of learning by doing and applying hands-on learning but mainly in the field of science (Ghosh, 2017). Hands-on learning developed first, and then it generated into mindson learning.

Hands-on learning is about learning by doing where learning can transform the abstract into concrete through manipulation of objects, tools and materials (Pike, O'Brien, Brownlow, Sanchez, Picot and Anderson, 2008). Minds-on learning refers to the fact that the learners are "interacting in depth and in a thoughtful manner with the learning content" (Sumil, 2016, p. 5).

There is a relationship between hands-on minds-on learning and manipulatives as they involve the learners 
physically and mentally. The use of manipulatives depends on using the hands by manipulating concrete objects and using the minds by helping students to think and reason (Stein and Bovalino, 2001)

The importance of applying manipulatives in kindergarten comes from the fact that children cannot learn abstractly until at least age 11 , and for some students it would take more time (Johnson, 2012). Using manipulatives reduces the anxiety that some children suffer from, and thus, increasing a positive attitude towards learning (Senyefia, 2017).

However, it has been observed through research that most studies that used manipulatives applied them to math and science (e.g. Senyefia, 2017; Johnson, 2012). On the other hand, using manipulatives in teaching languages has not been common (Belenky and Nokes, 2009, as cited in Nash, 2017). Thus, Sumil (2016) advocated the use of manipulatives to facilitate language learning.

When it comes to applying hands-on minds-on learning, creativity becomes an integral part of the learning process and the instruction itself (Seveckova, 2016). Product creativity can be in the form of either an art product or a craft product for developing young learners' learning (Green and Sinker, 2000). Art and craft works are not only related to learning by doing, but they are also related to the mind and cognitive skills (Farokhi and Hashemi, 2011), and they connect between the two hemispheres of the brain and foster cognitive skills (Vohra, 2018).

Hands-on minds-on learning decreases the amount of fear and threat that a child might feel in a traditional learning environment. It gives the opportunity that learning is treated as a practice period in which mistakes are allowed (Bartsch, 2017). Hands-on minds-on learning is a 
counterbalance to worksheets and tests, since it provides a different assessment technique that is free from test anxiety through using manipulatives (Blakey and McFadyen, 2015) or through product creativity assessment when creating art and craft works (Farokhi and Hashemi, 2011; Sumil, 2016).

\section{Method}

\subsection{Design of the Study}

The study applied the qualitative design. Since the collection of the data relied on the perspectives and personal opinions of the sample group about the effect of hands-on minds-on learning on the reduction of FLLA among kindergarteners while learning EFL, it did not seem possible to apply the quantitative and experimental research.

\subsection{Participants and Tools}

The sample group of the study consisted of 21 experts and EFL teachers in kindergarten in formal schools in Egypt. As for the tools of the study, interviews were used in order to collect qualitative data. The questions of the interview were about the perceptions of the kindergarten experts and EFL teachers about the effect of hands-on minds-on learning on reducing FLLA of kindergarteners.

\subsection{Procedure}

The study used a four-step procedure as follows:

\subsubsection{Step 1: Preparation}

After reviewing the literature and studies related to kindergarteners, their skills and effective instruction, FLLA and hands-on minds-on learning, the researcher prepared open-ended questions of interviews addressed to experts 
and EFL teachers in kindergarten. They were in the form of open-ended questions.

The following are the interview questions:

1. Can you describe how your kindergarteners react when they have to answer a question?

2. What do you do when you observe that a child is suffering from FLLA?

3. How can teachers alleviate FLLA among kindergarteners?

4. What are your experiences with hands-on minds-on learning?

5. Can you describe how kindergarteners react when they do an art or a craft activity like drawing or creating something with clay?

6. What are your views about using manipulatives in reducing FLLA?

7. What do you think about replacing traditional tests with other assessment techniques that involve using hands-on minds-on activities to alleviate FLLA?

8. What are your perceptions about the effect of using hands-on minds-on learning on reducing FLLA among kindergarteners?

\subsubsection{Step 2: Deductive Coding}

Since the researcher had already reviewed the literature of the study, it was easier to determine the themes of the codes before collecting the data as deductive coding. The researcher determined three themes: views about using hands-on minds-on learning with kindergarteners in EFL classes, experiences with FLLA among kindergarteners, and perceptions about methods to alleviate FLLA among kindergarteners. 


\subsubsection{Step 3: Data Collection}

The researcher had to give a brief introduction at the beginning about hands-on minds-on learning as some of the interviewees were not well aware of it. When she made sure that all had an idea about it, she started to ask them the questions. Then, she collected the data.

\subsubsection{Data Analysis}

After the data were collected, they were analyzed using the thematic codes in order to answer the research questions. Thus, from their answers, only words, phrases or sentences, that were related to their views about using hands-on minds-on with kindergarteners in EFL classes, their experiences with FLLA among kindergarteners, and their perceptions about methods of reducing FLLA among kindergarteners, were determined and highlighted.

\section{Results}

As seen from Table 1, results obtained from the study showed that $81 \%$ of the interviewees believed that handson minds-on learning could reduce kindergarteners' FLLA in EFL classes. They found it a "good approach" as children could use their hands and minds, and they perceived that when the hands and the mind were "engaged" in something the child loved to do, her/his level of FLAA might "decrease".

Only few of the interviewees could not make up their opinions because they either did not really experience FLLA among kindergarteners, or did not really use handson minds-on learning or that when they applied it through some activities like drawing or making letters with clay, it was "not systematic". 
Table 1. Perceptions of Interviewees about the Effect of Handson Minds-on Learning on Reducing FLLA among Kindergarteners

\begin{tabular}{|c|c|c|}
\hline No & $\begin{array}{l}\text { Perceptions of } \\
\text { Interviewees }\end{array}$ & Example Statements \\
\hline \multirow[b]{2}{*}{1} & \multirow{2}{*}{$\begin{array}{l}\text { About hands-on } \\
\text { minds-on learning }\end{array}$} & $\begin{array}{l}\text { "It is a good approach" } \\
\text { "When the hands and the mind were engaged in } \\
\text { something the child loved to do, her/his level of } \\
\text { FLAA might decrease" }\end{array}$ \\
\hline & & $\begin{array}{c}\text { "Well, I sometimes let them use blocks for knowing } \\
\text { letters, and play with clay to form letter shapes, } \\
\text { but in fact, I don't use it systematically or in my } \\
\text { lesson plans." }\end{array}$ \\
\hline No & $\begin{array}{l}\text { Perceptions of } \\
\text { Interviewees }\end{array}$ & Example Statements (Completed) \\
\hline 2 & $\begin{array}{l}\text { The Use of } \\
\text { Manipulatives }\end{array}$ & $\begin{array}{l}\text { "Manipulatives may reduce FLAA." } \\
\text { "I guess when children can touch them and there } \\
\text { are no abstract concepts, they can feel more at } \\
\text { ease." } \\
\text { "Children seem to like playing with blocks and } \\
\text { tokens. Although they may go out of control and } \\
\text { become noisy, but I can feel they are feeling safe } \\
\text { and not afraid at all." }\end{array}$ \\
\hline 3 & $\begin{array}{l}\text { Creating Art and } \\
\text { Crafts Works }\end{array}$ & $\begin{array}{l}\text { "I think children seem so engaged, motivated and } \\
\text { everyone comes up to me with much zest to show } \\
\text { me what they did. They feel so happy when they } \\
\text { create something. I always give them positive } \\
\text { feedback." } \\
\text { "I think art and craft works can reduce FLLA." }\end{array}$ \\
\hline 4 & $\begin{array}{l}\text { Assessment } \\
\text { Techniques other } \\
\text { than Traditional } \\
\text { Ones } \\
\end{array}$ & $\begin{array}{l}\text { "It will be much fun and children will not feel } \\
\text { worried or afraid." } \\
\text { "They will not feel they are questioned, but rather } \\
\text { they will feel more like they are playing." }\end{array}$ \\
\hline 5 & Traditional Methods & $\begin{array}{l}\text { "Some of them seem reluctant to answer or repeat } \\
\text { especially when they are asked individually. I am } \\
\text { not sure if they fear making mistakes, but I am } \\
\text { sure that they don't feel comfortable." } \\
\text { "I remember when a child had to answer a } \\
\text { question in the lesson, he started to feel a } \\
\text { stomachache, and I ended up not asking him." }\end{array}$ \\
\hline 6 & $\begin{array}{l}\text { Ways of Alleviating } \\
\text { FLLA }\end{array}$ & $\begin{array}{l}\text { "Teachers can be friendly with them. They can tell } \\
\text { stories and sing songs. } \\
\text { "They can engage them in activities they like and } \\
\text { find fun, like when they create things, draw, or } \\
\text { make crafts." }\end{array}$ \\
\hline
\end{tabular}


Most of them recommended the use of manipulatives to reduce FLLA as they change the "abstract into concrete", and when children "touch" them, they feel "more at ease". They also had positive perceptions about using art and craft works. They stated that they help the children to get "engaged", "motivated" and "happy".

As regards their experiences with FLLA among kindergarteners, some words and phrases were used in the answers, such as children feeling "reluctant to answer" "uncomfortable", "worried" and a case experienced a "stomachache" especially when answering questions individually.

Regarding the use of assessment techniques that are not traditional and that involve the use of hands-on minds-on activities, they also encouraged their use as a way to reduce FLLA. They thought it would be "much fun" and children will not feel "worried" or "afraid" as they will not feel they are "questioned, but rather playing."

As regards their perceptions about methods to alleviate FLLA, they had different views. For instance, they thought of ways based on their own experiences like being "friendly", besides engaging them in "activities" they like and find fun with, like when they "create things, draw, or make crafts."

\section{Discussion}

The aforementioned results confirmed that hands-on minds-on learning can reduce FLLA among kindergarteners in EFL classes. First, hands-on minds-on learning helps the learners to use their hands and minds. It helps in setting an environment that is free from fear of making mistakes as it is different from the traditional environment of classroom (Bartsch, 2017). 
Second, hands-on minds-on learning incorporates the use of manipulatives (Stein and Bovalino, 2001). They depend on using the hands by manipulating concrete objects and using the minds by helping students to think and reason as they access and activate different areas of the brain, besides making the abstract concrete which can reduce the anxiety. This confirms the studies of (Bartsch, 2017; Sidiqi, 2017; Senyefia, 2017; Shaaban, 2001).

Third, there is a relationship between hands-on minds-on learning and the creation of art and craft works. They are not only related to learning by doing, but they are also related to the mind and cognitive skills (Farokhi and Hashemi, 2011). Besides connecting between the two hemispheres of the brain for a better function and developing the learning process, they can help in increasing the children's motivation, and stressing their voice, choice and confidence which can alleviate their FLLA (Bartsch, 2017; Koolaee et al., 2016; Levy, 2011; Nelson, 2018).

Fourth, hands-on minds-on learning incorporates the use of assessment techniques that differ from the traditional ones, and which are free from test anxiety. This was perceived to be one of the factors of alleviating FLLA as (DeAngelis, 2010; Emery, 2018; Shaaban, 2001) confirmed.

Fifth, engaging the children in activities they like as they are fun and motivating, such as hands-on minds-on activities where both their hands and minds are engaged, was confirmed and reflected what (Tsiplakides et al., 2009) had stated about their positive effect in reducing FLLA.

\section{Conclusion}

The present study confirms that hands-on minds-on learning, which focuses on learning by using both the 
hands and the mind, can reduce the level of FLLA among kindergarteners. The use of manipulatives and the creation of art and craft works can help in reducing the level of FLLA. Besides, hands-on minds-on learning fosters a supporting classroom environment that is free from anxiety or fear from tests, quizzes and exercises. This is because the assessment methods are different from traditional assessment methods and can rely on using manipulatives and creating art and craft works which can alleviate the apprehension and anxiety that children might experience from tests or exercises.

This study recommends conducting quantitative researches to investigate the effect of hands-on minds-on learning on reducing FLLA among kindergarteners. As was displayed in the literature review, there is little research that investigated the use of hands-on minds-on learning in the field of learning foreign languages, and at the level of kindergarten. Besides, there is little research that investigated FLLA among kindergarteners. The study also recommends incorporating, on more systematic levels, hands-on minds-on activities in the English curriculum and as non-traditional assessment methods at formal schools.

\section{References}

- Ates, O. and Eryilmaz, A. (2011). Effectiveness of hands-on and minds-on activities on students' achievement and attitudes towards physics. [Available on line]. Retrieved April 23, 2019, from https://www.researchgate.net/publication/285947821 Effectiveness of hands-on and minds- on activities on students' achievement and attitudes towards physics

- Bartsch, C. (2017). Importance of a Hands-On Experience in the Elementary Classroom. [Available on line]. Retrieved August 20, 2017, from https://classroom.synonym.com/importance-handsonexperience-elementary-classroom-6701.html 
- Blaustein, M. (2005). The Basics of Learning Readiness. [Available on line]. Retrieved September 21, 2017, from https:// www.naeyc.org/files/yc/file/200507/01Blaustein.pdf

- Blakey, S. and McFadyen, J. (2015). Curiosity over conformity: the maker's palette - a case for hands-on learning. Art, Design \& Communication in Higher Education, 14 (2), 131-143. [Available on line]. Retrieved October 6th, 2018, from http://www. art.mmu.ac.uk/staff/research/5551

- Choi, N., Sheo, J., and Kang, S. (2020). Individual and Parental Factors Associated with Preschool Children's Foreign Language Anxiety in an EFL Setting. [Available on line]. Retrieved October $13^{\text {th }}, 2020$,from http://ilkogretim-online.org.tr/index.php/io/ article/ view/3814/2755

- Corzine, J., Davy, L., Spicer, W., and Jones, J. (2018). The Truth about Kindergarten. [Available on line]. Retrieved April $24^{\text {th }}, 2019$, from https://www.nj.gov/education/ece/k/truth.pdf

- Cowden, P. (2010). Communication and Conflict: Anxiety and Learning. [Available on line]. Retrieved October 17 ${ }^{\text {th }}, 2019$ from https://www.researchgate.net/publication/242757748_Communica tion_and_conflict_Anxiety_and_learning

- DeAngelis, T. (2010). Social Awareness + Emotional Skills = Successful Kids. [Available on line]. Retrieved September 21, 2016, from http://www.apa.org/monitor/2010/04/ classrooms.aspx

- Ed, S., Church, E., Poole, C. (2016). Ages \& Stages: How Children Develop Motor Skills. [Available on line]. Retrieved September 21st, 2016, fromhttp://www. scholastic.com/ teachers/ article/ages-stages-how-children-develop-motor-skills

- Emery, H. (2018). Assessing Young Learners. [Available online]. Retrieved August $16^{\text {th }}$, 2019, from https://onlinelibrary.wiley. com/doi/pdf/10.1002/9781118784235.eelt0382

- Farokhi, M. and Hashemi, M. (2011). The impact/s of using art in English language learning classes. Procedia - Social and Behavioral Sciences, 31, 923 - 926. [Available online]. Retrieved July 4, 2019, from https://www.sciencedirect.com/ science/ article/pii/S1877042811030990

- Ghosh, T. (2017). Does the 'Hands on Minds on' Approach in Science Museums and Centres Enhance Scientific Engagement in Children between 10-14 Years Old? [Available on line]. Retrieved April13th,2019,fromhttps://www.researchgate.net/publication /312219771 
- Green, J. and Sinker, R. (2000). Evaluating Creativity: Making and Learning by Young People. London: Routledge.

- Hoque, M. (2017). Three Domains of Learning: Cognitive, Affective and Psychomotor. [Available on line]. Retrieved September 25th, 2019, from https://www.researchgate .net/ publication/330811334_Three_Domains_of_Learning_Cognitive_ Affective_and_Psychomotor

- Johnson, A. (2012). The Effects of Mathematics Manipulatives on Middle Childhood Students. [Available online]. Retrieved May $1^{\text {st }}$ ,2019, from https://etd.ohiolink.edu/!etd.send_file? accession= oduhonors 1337271589\&disposition=inline

- Koolaee, K.,Vazifehdar R., Bahari, F. and Akbari, M. (2016). Impact of Painting Therapy on Aggression and Anxiety of Children with Cancer. [Available on line]. Retrieved December $6^{\text {th }}, 2019$, from http://caspianjp.ir/article-1-51-en.pdf

- Kralova, Z. (2016). Foreign Language Anxiety. [Available on line]. Retrieved February 13 ${ }^{\text {th }}, 2020$, from https://www. researchgate.net/publication/312918924_Foreign_Language_Anxi ety

- Levy, N. (2011). The Effectiveness of Art Therapy on Levels of Anxiety in Children. [Available on line]. Retrieved January $12^{\text {th }}$, 2020, from https://www.tati.on.ca/wp-content/uploads/2012/02/ The-Effectiveness-of-Art-Therapy-on-Levels-of-Anxiety-in-

Children-by-Nicole-Ley-2011-thesis-proposal.pdf

- Nash, J. (2017). Using Hands-on Manipulatives. Retrieved May $1^{\text {st }}, 2019$, from https://www.languagemagazine.com/using-handson-manipulatives/

- Nelson, G. (2018). Perceptions About Hands-On Art Making by Non- Art Major Online Students. [Available on line]. Retreived May $7^{\text {th }}, 2019$, from https://scholarworks.waldenu.edu/ cgi/view content.cgi article $=6920 \&$ context $=$ dissertations

- Nilsson, M. (2019). Foreign Language Anxiety: The Case of Young Learners of English in Swedish Primary Classrooms. [Available on line]. Retreived August 4 ${ }^{\text {th }}$, 2020, from http:// apples.jyu.fi/ArticleFile/download/1048

- Pike, D., O’Brien, M., Brownlow, M., Sanchez, G., Picot, K., and Anderson, T. (2008). Kindergarten Integrated Curriculum Document. [Available on line]. Retrieved September 16, 2018, from, http://www.gov.pe.ca/photos/original/k_doc.pdf 
- Rahimi, A. and Mansoori, T. (2016). A Teacher's Action Research: Diminishing Students' Foreign Language Classroom Anxiety [Available on line]. Retrieved September $19^{\text {th }}, 2019$ from https://www.researchgate.net/publication/290821298_A_Teacher' s_Action_Research_Diminishing_Students'_Foreign_Language_C lassroom_Anxiety

- Seveckova, M. (2016). Creativity in Foreign Language Teaching. [Available on line]. Journal of Education Culture and Society (2), pp. 180 - 188. Retrieved May $1^{\text {st }}, 2019$ from https://jecs.pl/index. php/jecs/article/view/10.15503.jecs20162.180.188/pdf

- Shaaban, K. (2001). Assessment of Young Learners. [Available on line]. Retrieved August 5th, 2019, from https://www. researchgate.net/publication/234709045_Assessment_of_Young Learners

- Senyefia, B. (2017). Effect of physical and virtual manipulatives on the mathematical achievement of junior high school students in the topic of transformation in Ghana. Asian Research Journal of Mathematics, 4(4), 1-14. [Available on line]. Retrieved April 29th, 2019, from http://www.journalrepository.org/media/ journals/ARJOM 44/2017/Jun/Senyefia442017ARJOM34238.pdf

- Shin, J. (2019). Ten Helpful Ideas for Teaching English to Young Learners. American English E-Teacher Program._[Available on line]. Retrieved May $1^{\text {st }}$, 2019, from https://americanenglish. state.gov/files/ae/resource_files/joan_kang_shin_ten_helpful_idea s_for_teaching english to young learners.pdf

- Sidiqi, N. (2017). Effective Strategies to Reduce Math Anxiety in Teachers and Students. [Available on line]. Retrieved April $9^{\text {th }}$, 2019 fromhttps://tspace.library.utoronto.ca/bitstream/1807/77195/ 1/ Sidiqi_Nilab_201706_MT_MTRP.pdf

- Stein, M. and Bovalino, J. (2001). Manipulatives: One Piece of the Puzzle. [Available on line]. Retrieved September 21, 2017, from https://www.researchgate.net/publication/234678185 anipulatives _One_Piece_of_the_Puzzle

- Sumil, N. (2016). The Minds-On Hearts-On Hands-On Learning Engagements: An Applied Research and Development Based Initiative in an African University and Accentuates a Training Track for Educators/Enablers. Norderstedt: GRIN Publishing

- Thies, T. (2014). Affective Learning Experiences Influence Positive Interactions with Anxiety: Comprehensive Musicianship with Seventh Grade Jazz Students. [Available on line]. Retrieved 
July $19^{\text {th }}, 2019$ from https://ir.uiowa.edu/ cgi/viewcontent. cgi? article $=5445 \&$ context $=$ etd

- Tsiplakides, I. and Keramida, A. (2009). Helping Students Overcome Foreign Language Speaking Anxiety in the English Classroom: Theoretical Issues and Practical Recommendations. [Available on line]. Retrieved July 25 ${ }^{\text {th }}$, 2018, from https://files.eric.ed.gov/fulltext/EJ1065743.pdf

- Vohra, A. (2019). News Flash: A Child Learns Way Better Through Creativity. [Available on line]. Retrieved July 16, 2019, from https://www.thehindu.com/thread/arts-culture-society/newsFLLAsh-a-child-learns-way-better-throughcreativity/article26204265.ece

- Zapata, G. (2017). Teaching English Through Arts and Crafts to Third Grade Public School Children at Institute Educativa Suroriental de Pereira. [Available online]. Retrieved July 15, 2019, from http://repositorio.utp.edu.co/dspace/bitstream/handle/ 11059/8045/4280071G633.pdf?sequence $=1$

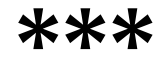

